\title{
CD4 Percentage and Absolute CD4 Accuracy not Different in Predicting Viral Load of HIV-Infected Mothers
}

\author{
Akurasi Persentase CD4 dan Absolut CD4 tidak Berbeda dalam \\ Memprediksi Viral Load pada Ibu Hamil Terinfeksi HIV
}

\author{
Ferry Santoso, Ketut Suwiyoga, I Gede M Putra \\ Department of Obstetrics and Gynecology \\ Faculty of Medicine University of Udayana/ \\ Sanglah General Hospital \\ Bali
}

\begin{abstract}
Objective: To determine the accuracy difference between CD4 percentage and absolute CD4 in predicting the viral load of HIV-infected pregnant women.

Methods: This study is a diagnostic study involving 22 HIV-infected pregnant women who came for PMTCT at the Outpatient Clinic in Sanglah Hospital, from September 2011 until August 2012, who were randomly selected through consecutive sampling. Blood samples were collected to analyze the viral load, CD4, and complete blood count (CBC). Viral load examination was conducted using PCR in the molecular biology laboratory in the Faculty of Medicine University of Udayana. CD4 and CBC test was conducted in Sanglah Hospital Laboratory. Analysis was done with $2 \times 2$ table using SPSS for windows ${ }^{\circledR}$ version 17 to evaluate sensitivity, specificity and accuracy rate of $\mathrm{CD} 4$ percentage and absolute $\mathrm{CD} 4$ in predicting the viral load.

Results: Data analysis shows that CD4 percentage had 75.0\% sensitivity, $88.9 \%$ specificity, and accuracy of $86.4 \%$ for predicting the viral load in HIV-infected pregnant women. Meanwhile, absolute CD4 had $50.0 \%$ sensitivity, $77.8 \%$ specificity, and $72.7 \%$ accuracy. Chisquare test shows that there was no significant difference in the accuracy of CD4 percentage and absolute CD4 ( $p=0.457)$.

Conclusion: CD4 percentage and absolute CD4 had high accuracy in predicting the viral load in HIV-infected pregnant women $86.4 \%$ and $72.7 \%$ ). There was no significant difference of accuracy between the CD4 percentage and absolute CD4.

[Indones J Obstet Gynecol 2015; 3-4: 230-233]
\end{abstract}

Keywords: CD4, HIV-infected pregnant women, viral load

\begin{abstract}
Abstrak
Tujuan: Untuk mempelajari perbedaan akurasi antara persentase CD4 dibandingkan CD4 absolut dalam memprediksi viral load pada ibu hamil terinfeksi HIV.

Metode: Penelitian uji diagnostik ini melibatkan 22 ibu hamil terinfeksi HIV yang datang ke Poliklinik PMTCT RSUP Sanglah, dari bulan September 2011 sampai dengan Agustus 2012, yang diambil secara consecutive sampling. Darah diambil untuk pemeriksaan viral load, $C D 4$, dan darah lengkap (DL). Pemeriksaan viral load dilakukan dengan PCR di laboratorium biologi molekuler FK Universitas Udayana. Pemeriksaan CD4 dan DL dilakukan di laboratorium RSUP Sanglah. Dilakukan analisis dengan tabel silang $2 \times 2$ menggunakan SPSS for Windows $($ version 17 untuk menilai sensitivitas, spesifisitas, dan tingkat akurasi antara persentase CD4 dan CD4 absolut untuk menilai viral load HIV.
\end{abstract}

Hasil: Hasil analisis menunjukkan persentase CD4 memiliki sensitivitas sebesar 75,0\%, spesifisitas sebesar 88,9\%, dan akurasi sebesar 86,4\% dalam memprediksi viral load pada ibu hamil terinfeksi HIV. Sedangkan, CD4 absolut memiliki sensitivitas 50,0\%, spesifisitas 77,8\%, dan akurasi sebesar 72,7\%. Hasil uji Chi-Square menunjukkan tidak ada perbedaan bermakna antara akurasi persentase CD4 dan CD4 absolut $(p=0,457)$.

Kesimpulan: Persentase CD4 dan CD4 absolut memiliki akurasi yang tinggi dalam memprediksi viral load pada ibu hamil terinfeksi HIV (86,4\% dan 72,7\%). Tidak terdapat perbedaan akurasi yang bermakna antara persentase CD4 dan CD4 absolut.

[Maj Obstet Ginekol Indones 2015; 3-4: 230-233]

Kata kunci: CD4, ibu hamil terinfeksi HIV, viral load

Correspondence: Ferry Santoso, Jln. Apokat I no. 59, Kertosono, Nganjuk, Jawa Timur, Email: dr.ferrysantoso@gmail.com

\section{INTRODUCTION}

Pregnancy that is infected with HIV needs serious attention. Based on UNAIDS data in 2009, there are 33.3 million HIV cases throughout the world, with increasing number of cases being around 2.6 million per year. About 15.9 million (48\%) among that number are women, and 2.5 million cases are found in young teenagers below 15 years old. More than $90 \%$ of cases in children are due to the transmission between mothers to the fetus. Gray and
Mclntyre have previously shown that $8.5 \%$ among all HIV patients are pregnant women that deliver babies each year. ${ }^{1,2}$

High viral load (VL), defined as VL $\geq 10.000$ copies $/ \mathrm{ml}$, is the main risk factor for HIV transmission from mother to the fetus throughout pregnancy, labor, and breastfeeding. If the VL is less than 1000 copies $/ \mathrm{ml}$, then the perinatal transmission risk is very low. VL is the main key in the prevention of HIV transmission from the mother to the fetus. VL 
test is also important in analyzing body response towards ARV, knowing the perinatal transmission risk earlier, and choosing the appropriate delivery method in order to minimize the transmission risk. However, VL examination needs very high cost and can only be tested in a laboratory that is equipped with PCR. Laboratory with PCR facility is only available in a big city, especially in Java Island. Meanwhile, the number of HIV-infected pregnant women is very high especially in suburban areas, such as Papua. ${ }^{3-5}$

CD4 is used to determine the immunity status of an HIV patient by measuring the absolute CD4 number and percentage. The higher rate of HIV VL means that the CD4 is low in the patient. The examination of immune system with CD4 is economically reasonable, fast and available in many places in Indonesia. There is a correlation between a low immune system with the high HIV VL. As a result the percentage of CD4 and absolute CD4 can be used to predict HIV VL in the pregnant women's circulation.

This study was conducted to evaluate the accuracy of CD4 percentage and absolute CD4 in predicting VL in pregnant women circulation that are infected with HIV. If one or both of those examination have good sensitivity and specificity to predict HIV VL, then this examination can be used as an alternative in analyzing HIV VL during antenatal care (ANC) especially in areas with limited resources.

\section{METHODS}

This study was a diagnostic study (analytic observational cross-sectional). This study was conducted to determine the difference of accuracy between CD4 percentage compared to absolute CD4 in predicting the VL in HIV-infected pregnant women. We used Polymerase Chain Reaction (PCR) as the gold standard to evaluate VL in HIV-infected pregnant women. CD4 percentage was manually counted based on the comparison of absolute CD4 and total lymphocyte count in percentage.

This study was conducted in the outpatient clinic of the Department of Obstetrics and Gynecology, especially in PMTCT clinic of Sanglah Hospital, Denpasar, starting from September $1^{\text {st }} 2011$ until August $31^{\text {st }}$ 2012. Samples were HIV-infected pregnant women who presented for PMTCT in Sanglah Hospital during the period of September $1^{\text {st }} 2011$
- August 31 2012 who fulfilled the inclusion criteria and were willing to join this study that were selected with consecutive sampling. Inclusion criteria of this study were patients with a confirmed diagnosis of HIV/AIDS based on HIV antibody examination with the standard method in Sanglah Hospital, in their second and third trimester, willing to come to the PMTCT department in the morning, and willing to join the study. Exclusion criteria of this study were malnutrition (BMI < 18.5), had burn wound, and had undergone splenectomy.

Sample number was calculated using Lameshow formula and the result was 22 samples. Samples were obtained from the peripheral vein circulation of HIV-infected pregnant women as much as $6 \mathrm{cc}$ that was inserted in EDTA tube (3 cc) for CD4 and $\mathrm{CBC}$ examination, and tube without EDTA $(3 \mathrm{cc})$ for HIV viral load. Samples were sent to the Clinical Pathology Laboratory of Sanglah Hospital for CD4 and CBC examination, and Molecular Biology Laboratory Faculty of Medicine Udayana for PCR examination.

Data analysis was conducted using SPSS 17.0 for Windows program and data was presented using table and narration. Descriptive analysis was done to evaluate maternal characteristics such as age, education, occupation, parity, gestational age, and BMI. Data was inserted in a $2 \times 2$ table and evaluated for sensitivity, specificity, positive predictive value, negative predictive value, positive likelihood ratio, and negative likelihood ratio.

\section{RESULTS AND DISCUSSION}

Table 1. Characteristics Distribution of Age, Parity, Gestational Age, and BMI

\begin{tabular}{lccc}
\hline \hline \multicolumn{1}{c}{ Variable } & Mean & SD & Range \\
\hline Age (year) & 24.73 & 3.87 & $19-34$ \\
Parity & 1.73 & 0.88 & $1-4$ \\
Gestational age (week) & 28.73 & 4.86 & $18-36$ \\
BMI & 23.40 & 3.84 & $19.10-34.20$ \\
\hline \hline
\end{tabular}

Based on the table above, the mean age of the study sample was $24.73 \pm 3.87$ with a range of 19 34 years old. Mean parity was $1.73 \pm 0.88$ with a range of 1-4. The mean of gestational age was $28.73 \pm 4.86$ weeks, with a range of $18-36$ weeks gestational age. Furthermore, the mean BMI was $23.40 \pm 3.84 \mathrm{~kg} / \mathrm{m}^{2}$ with a range between 19.10 $34.20 \mathrm{~kg} / \mathrm{m}^{2}$. 
Table 2. 2x2 Table of Absolute CD4 Towards HIV Viral Load

\begin{tabular}{rcccc}
\hline \hline & \multicolumn{3}{c}{ Viral Load } & Total \\
\cline { 3 - 4 } & & $\geq \mathbf{1 0 , 0 0 0}$ & $<\mathbf{1 0 , 0 0 0}$ & \\
\hline \multirow{3}{*}{ Absolute CD4 } & $\leq 200$ & 2 & 4 & 6 \\
& $>200$ & 2 & 14 & 16 \\
Total & & 4 & 8 & 12 \\
\hline \hline
\end{tabular}

In this study, the sensitivity of absolute CD4 towards HIV viral load was $50.0 \%$, with specificity of $77.8 \%$, positive predictive value of $50.0 \%$, negative predictive value of $87.5 \%$, positive likelihood ratio was 2.3 , and negative likelihood ratio was 0.64 . The cutoff point of absolute CD4 that was used in this study was 200 cells/ml. CD4 that was less than 200 cells/ml will increase the transmission of HIV significantly and having higher risk of opportunistic infection. The low CD4 and high VL number is the risk factor of transmission from mother to fetus. ${ }^{6,7}$

Table 3. $2 \times 2$ Table of CD4 Percentage Towards HIV Viral Load

\begin{tabular}{ccccc}
\hline \hline & \multicolumn{3}{c}{ Viral Load } & Total \\
\cline { 2 - 4 } & & $\geq \mathbf{1 0 , 0 0 0}$ & $<\mathbf{1 0 , 0 0 0}$ & \\
\hline \multirow{2}{*}{ CD4 Percentage } & $\leq 13$ & 3 & 2 & 6 \\
Total & $>13$ & 1 & 16 & 16 \\
\hline \hline
\end{tabular}

In this study, the CD4 percentage sensitivity towards HIV viral load was $75.0 \%$, specificity was $88.9 \%$, positive predictive value was $60.0 \%$, negative predictive value was $94.1 \%$, positive likelihood value was 6.76 , and negative likelihood value was 0.28 . The cutoff point of VL was 10,000 copies $/ \mathrm{ml}$, based on the fact that HIV VL at that number or more than that will increase the risk of transmission from mother to fetus significantly. The cutoff point of CD4 percentage that was used in this study was $13 \%$, since it was within the same range of absolute CD4 of 200 cells/ml. The high sensitivity and specificity showed the ability of CD4 percentage in predicting HIV VL in maternal circulation. It means, this study can be used to evaluate the effectiveness of ARV and transmission risk of HIV from mother to fetus. ${ }^{7-9}$

This study showed that absolute CD4 and CD4 percentage had high accuracy. Accuracy of absolute CD4 used to predict HIV VL was $72.7 \%$, while the CD4 percentage had an accuracy of $86.4 \%$. Based on the Chi-Square test, there was no significant difference between absolute CD4 and CD4 percentage accuracy $(\mathrm{p}=0.457)$.

Table 4. Comparison of Absolute CD4 and CD4 Percentage Accuracy Towards HIV Viral Load

\begin{tabular}{lcccccc}
\hline \hline \multirow{2}{*}{ Examination } & \multicolumn{2}{c}{ Accuracy } & Total & $\%$ & $\mathbf{p}$ \\
\cline { 2 - 5 } & \multicolumn{2}{c}{ Accurate } & Not Accurate & & & \\
\hline Absolute CD4 & 16 & 6 & 22 & 72.7 & 0.457 \\
\hline CD4 Percentage & 19 & 3 & 22 & 86.4 & \\
\hline \hline
\end{tabular}

This study showed that CD4 percentage and absolute CD4 was accurate enough to describe the viral load condition in HIV-infected pregnant women. The lower CD4 count indicated a weaker immune system of the patient, and vice versa. This was probably caused by the fact that cells that contained CD4 was being the main target of HIV infection. Cells that have CD4 receptors, which are lymphocytes (T helper cell), monocytes/macrophages, dendritic/Langerhans cells, are the cells that are responsible in keeping human immunity, and these are the targets of HIV infection. HIV is related with cell target through CD4. Together with the viral replication, there was a destruction of the immune system, especially $\mathrm{T}$ Helper lymphocytes. The more immune cells are destroyed, will cause a higher viral load in the patient. ${ }^{10}$

Controlled variable in this study was malnutrition, diurnal variation, patients with burn wound, and history of splenectomy. Meanwhile, the variables that are not fully controlled are hemodilution and psychosocial stress. This study showed that hemodilution does not really affect the absolute CD4 count. Even though hemodilution could cause a variation of absolute CD4 number, but the range of variation does not reduce its ability to describe the immune condition of HIV patient. As the result, absolute CD4 still has a high rate of accuracy in predicting HIV VL.

CD4 percentage is known to be more stabile, and the result is not affected by other variables. This was probably due to CD4 percentage that consists of functional lymphocyte, which was CD4. CD4 percentage considers the total number of lymphocyte to evaluate the immune system. This study result also showed that CD4 percentage has better function in predicting VL in HIV-infected pregnant women with high accuracy, which was $86.4 \%$. In some extreme situations, such as malnutrition, 
burn wounds, and splenectomy history, CD4 percentage is more superior. ${ }^{11}$

CD4 percentage examination is not a difficult and expensive examination. CD4 percentage can be manually evaluated based on a ratio of absolute CD4 and total lymphocyte count, expressed in percentage unit (\%). Total lymphocyte count is obtained from routine CBC examination during ANC. CD4 percentage could be obtained from all patients who went for ANC in the outpatient department. As the result, the HIV VL could also be evaluated during ANC based on the CD4 percentage. Using the $13 \%$ cutoff point, if the CD4 percentage is less than the predetermined cutoff point, it could be concluded that HIV VL in the maternal circulation could be more than 10,000 copies $/ \mathrm{ml}$ with $86.4 \%$ accuracy.

CD4 percentage examination is planned to be one of the alternative examination beside PCR in evaluating viral load in HIV-infected pregnant women. This examination is simpler, less expensive and hopefully could be performed in all hospitals, which are appointed to manage HIV patients throughout Indonesia. Laboratory staff also does not need special training since this examination is simple.

The weakness of this study was that this study was an introductory study to assess HIV VL based on immune status during pregnancy. There was no previous or similar study in other places. As the result, this study could not be compared with other studies. Moreover, this study only involves HIV-infected pregnant women in the second and third trimester. Informative value would be higher if the study involved all trimesters of pregnancy.

The duration of ARV admission also could not be fully controlled in this study. Even though all samples within this study already received ARV, but it would be probably better if the samples were divided into two groups, which were patients that had not received ARV yet, and the patients who already received ARV previously. In the group with patients who received ARV could be further categorized into few groups based on the duration of ARV consumption.

\section{CONCLUSION}

CD4 percentage and absolute CD4 had high accuracy in predicting viral load in HIV-infected pregnant women $(86.4 \%$ and $72.7 \%)$. There was no significant difference of accuracy between CD4 percentage and absolute CD4. Further studies are required involving samples from different centers (multicenter study) in order to provide better informative result.

\section{REFERENCES}

1. UNAIDS. Global Summary of the AIDS epidemic. [Online]. 2009. Available from: URL:www.unaids.org/documents/ 20101123_GlobalReport_em.pdf

2. Gray GE, Mclntyre JA. Pregnancy Plus: HIV and pregnancy. BMJ 2007; 334(7600): 950-3.

3. De Cock KM, Fowler MG, Mercier E, et al. Prevention of mother-to-child HIV transmission in resource-poor countries. JAMA 2000; 283(9): 1175-82.

4. Depkes RI. Pedoman nasional pencegahan penularan HIV dari ibu ke bayi. Jakarta: Departemen Kesehatan RI; 2006.

5. Prieto LM, Gonzalez-Tome MI, Munoz E, et al. Mother to Child Transmission of HIV-1 and Risk Factors. Pediatr Infect Dis J 2011; 31(10): 1053-8.

6. Money D, Tulloch K, Boucoiran I, et al. British Columbia guidelines for the care of HIV positive pregnant women and interventions to reduce perinatal transmission. [Online]. 2013. Available from: URL:http://www.cfenet.ubc.ca/sites/ default/files/uploads/docs/guidelines/BC_HIV_in_pregnancy_guidelines.pdf.

7. Ayisi JG, Van Eijk AM, Newman RD, et al. Maternal malaria and perinatal HIV transmission, Western Kenya. Emerg Infect Dis. 2004 ; 10(4): 643-52.

8. Ahir SP, Chavan V, Kerkar S, et al. Antiretroviral treatment, viral load of mother \& perinatal HIV transmission in Mumbai, India. Indian J Med Res. 2013; 138: 201-8.

9. Jourdain G, Mary JY, Coeur SL, et al. Risk factors for utero or intrapartum mother-to-child transmission of human immunodeficiency virus type 1 in Thailand. J Infect Dis 2007; 196(11): 1629-36.

10. Cichocki M. Understanding Absolute CD4 Count and CD4 Percentage. [Online]. 2014. Available from: URL:http://aids. about.com/od/ aidsfactsheets/a/cd4percent.htm.

11. Fauci AA, Lane C. Human immunodeficiency virus disease: AIDS and related disorders. In: Longo DL, Kasper DL, Jameson JL, et al. (eds). Harrison's principles of internal medicine. 18 $8^{\text {th }}$ Ed. New York: McGraw-Hill Companies; 2012. 